\title{
Elements of the "new economy" and innovative development as strategic priorities for strengthening the competitive position of the regions
}

\author{
Olga Yurievna Michurina \\ Astrakhan state technical University \\ Institute of economics \\ Astrakhan, Russia \\ michurina@list.ru
}

\author{
Natalia Alexsandrovna Dubinina \\ Astrakhan state technical University \\ Institute of economics \\ Astrakhan, Russia
}

\author{
Elena Yurievna Barmina \\ Saint-Petersburg state \\ economic University \\ Faculty of business, customs and \\ economic security \\ Saint Petersburg, Russia
}

\begin{abstract}
The widespread development of information and communication technologies, the introduction of innovations led to the transition to a new stage of economic development, which was called "new economy". At the highest level, the authorities declared the priority role of the development of the innovation system in the Russian economy, which necessitates the coordination and development of scientific, technical and innovation activities in the regions. Systematic and long-term work to support innovation in the Astrakhan region has contributed to the fact that the sector of innovative entrepreneurship plays an increasingly prominent role in the economy of the region. New requirements for the development of regional industry have increased the receptivity of business to innovation. The distinctive features of the "new economy" and the directions of innovative development of the Russian economy in the long term determine their use as strategic priorities of economic development at the regional level, which will inevitably contribute to the strengthening of competitive positions, both regions and the country as a whole.
\end{abstract}

Keywords - postindustrial economy, new economy, distinctive features of the new economy, innovative development, innovative scenario, innovations in the Astrakhan region

\section{INTRODUCTION}

The current stage of economic development is characterized as the economy of post-industrial society, which has priority in the production of services rather than goods, which is based on the paramount importance of information, knowledge, research, learning, education, creativity thinking workers. The new economy focuses not on the development of knowledge as such, but on the transformation of high technologies, primarily information, into the main factor in improving the efficiency of modern production. That is why the leading economies are now building their development along the innovative path, thus moving to a fundamentally new stage of progress.

\section{MATERIALS AND METHODS}

The study was based on the concepts, classifications, approaches presented in scientific research in the field of stages of economic development, distinctive features of the post-industrial economy, the formation of the concept of "new economy", identifying the characteristics and characteristics of the "new economy", innovative development path. General scientific methods of historical and logical, systemic, evolutionary, comparative and descriptive, statistical and morphological analysis were used in the preparation of the article.

The legislative and regulatory acts of the President, the government of the Russian Federation, as well as the authorities and management of the Astrakhan region served as the legal basis for the study.

The information and empirical base of the study was made up of data of the Federal state statistics service, regional statistical committees, strategies and programs of social and economic development of the Russian Federation and Astrakhan region, and other materials. 


\section{RESULTS}

\section{A. Distinctive features of the" new economy " as a prerequisite for innovative development}

Production of tangible goods remains one of the primary tasks of the economy, but in the cost of production becomes more and more important services, another words advertising, marketing promotion of goods, trade, creating and maintaining an image, research and development, patents. The result of the work of an increasing number of personnel is the information that is created, accumulated, developed, justified, acquires the characteristics of confidential and even secret, is of great value in management decisions. The production of information is more viable than material production, since the main costs are in the initial stage of creation of information models - plans, strategies, models, landmarks, traditions, methods, techniques, regulations, etc. When copying and printing expenses are no longer significant.

In the post-industrial economy, time becomes a new factor of competition. Ownership of information, instant information, the speed of information transfer around the globe provide companies to achieve a competitive advantage. Information becomes on one level with the classical system-forming resources allocated in economic science (land, capital, labor). Widely used automation of production can significantly reduce the role of physical labor in the production process. Priority workers are not workers engaged in the processing of objects of labor using the means of labor, but employees, the product of which is the management information. Private property business, individual ownership of enterprises weakens its position against the backdrop of an increasing proliferation of large integrated corporate structures, in which joint-stock property prevails. The source of capital is not only tangible assets, but also securities, licenses, patents, registered trademarks, as well as property rights to other intangible assets.

The comparison of factors of preindustrial, industrial and postindustrial phases of economy carried out by the authors is presented in table I.

During the development of the post-industrial economy, we are increasingly faced with the concept of "new economy". In the most General form, the distinctive features of the new economy are: a significant share of innovative projects in the activities of companies; higher growth of production renewal, exceeding the average rates in the real economy sectors; a certain share of the uniqueness of intangible assets used; a significant share of intellectual human capital in investment.

Despite the fact that, in our opinion, the concept of "new economy" should be interpreted broadly, and to some extent, it is identical to the post-industrial stage of economic development, it is impossible not to recognize the predominant
TABLE I. COMPARISON OF FACTORS PREINDUSTRIAL, INDUSTRIAL AND POST-INDUSTRIAL ECONOMY

\begin{tabular}{|c|c|c|c|}
\hline Factors & $\begin{array}{c}\text { Preindustrial } \\
\text { economy }\end{array}$ & $\begin{array}{c}\text { Industrial } \\
\text { economy }\end{array}$ & $\begin{array}{c}\text { Post-industrial } \\
\text { economy }\end{array}$ \\
\hline $\begin{array}{l}\text { Basis of } \\
\text { creation of } \\
\text { cost of } \\
\text { material goods } \\
\text { (production) }\end{array}$ & $\begin{array}{l}\text { Procurement } \\
\text { of raw } \\
\text { materials }\end{array}$ & $\begin{array}{l}\text { The processing of } \\
\text { raw materials }\end{array}$ & $\begin{array}{l}\text { The service } \\
\text { sector (trade, } \\
\text { marketing, } \\
\text { advertising, R \& } \\
\text { d, patents, etc }\end{array}$ \\
\hline $\begin{array}{l}\text { The main } \\
\text { category of } \\
\text { human } \\
\text { resources }\end{array}$ & Peasants & $\begin{array}{l}\text { Workers engaged } \\
\text { in the processing } \\
\text { of objects of } \\
\text { labor using means } \\
\text { of labor }\end{array}$ & $\begin{array}{l}\text { Employees } \\
\text { involved in the } \\
\text { processing of } \\
\text { management } \\
\text { information }\end{array}$ \\
\hline $\begin{array}{l}\text { The driving } \\
\text { factors of } \\
\text { economic } \\
\text { growth }\end{array}$ & $\begin{array}{l}\text { The driving } \\
\text { factors of } \\
\text { economic } \\
\text { growth }\end{array}$ & $\begin{array}{l}\text { The additional } \\
\text { energy that is } \\
\text { created by } \\
\text { combining the } \\
\text { individual } \\
\text { components of } \\
\text { the production } \\
\text { process }\end{array}$ & $\begin{array}{l}\text { The possession } \\
\text { of information }\end{array}$ \\
\hline $\begin{array}{l}\text { Strategically } \\
\text { important } \\
\text { resources }\end{array}$ & $\begin{array}{l}\text { Food, raw } \\
\text { materials, } \\
\text { materials }\end{array}$ & $\begin{array}{l}\text { Capital, } \\
\text { accumulated } \\
\text { traditions, } \\
\text { regulations, } \\
\text { technologies }\end{array}$ & $\begin{array}{l}\text { Education, } \\
\text { intellectual } \\
\text { property, } \\
\text { knowledge, } \\
\text { competence }\end{array}$ \\
\hline $\begin{array}{l}\text { Methods of } \\
\text { management } \\
\text { decision- } \\
\text { making }\end{array}$ & $\begin{array}{l}\text { Intuition, past } \\
\text { experience, } \\
\text { common sense }\end{array}$ & $\begin{array}{l}\text { Judgment testing, } \\
\text { research }\end{array}$ & $\begin{array}{l}\text { Models, } \\
\text { forecasts, } \\
\text { theoretical bases } \\
\text { of decision- } \\
\text { making }\end{array}$ \\
\hline $\begin{array}{l}\text { Forms of } \\
\text { production } \\
\text { organization }\end{array}$ & $\begin{array}{l}\text { Private } \\
\text { individual } \\
\text { family } \\
\text { business }\end{array}$ & $\begin{array}{l}\text { Joint stock } \\
\text { company }\end{array}$ & $\begin{array}{l}\text { Integrated } \\
\text { structures- } \\
\text { networks, } \\
\text { clusters, holdings }\end{array}$ \\
\hline
\end{tabular}

role of the activation of information and communication technologies, innovation, development and consolidation positions of global information systems, e-Commerce in the transition to a new stage of development, which is called the new economy. According to E. V. Avdokushin, "New economy" is not just a noticeable trend or phenomenon (correlated with the stock market or the Internet), but a new era in the development of a globalizing world economy, the material basis of a post - industrial information society " [1]. The author believes that the mechanism of development of the new economy does not exist in itself, but structurally develops in parallel to the mechanism of existence of the traditional economy, in some cases originates from its forms, in othersinteracts in them, forms integrated structures, new forms and methods of economic functions.

Analysts of the company "Business Engineering Groups," for more than 15 years working in research development, management consulting, training activities and the development of software products in the field of businessengineering, defines the new economy as "continuous synthesis of something new from already known and available for the decision of problems of growth of welfare of the most socially acceptable methods" [2]. The most common interpretation in the scientific literature can be called the definition of a new economy, as "... the economy of a society based on knowledge, innovation, friendly perception of new ideas, machines, systems and technologies, the readiness of 
their practical implementation in various spheres of human activity" [3].

The distinctive features of the new economy are summarized in table II.

Thus, in the post-industrial society, unlike the industrial one, a significant part of production is the non-material sphere of services. Parallel broad development of information and communication technologies, introduction of innovations led to the transition to a new stage of economic development, which was called "new economy". At the beginning of the 21 st century information and system macrotechnologies, accelerated formation of knowledge-intensive structures came to the fore; processes that allow to provide multiplicative increment of the effect in the development of knowledgeintensive production and innovation systems.

"The modern evolution of the economy on the basis of changes in the traditional economic structure is accompanied by increased competition for innovations, which from the means of achieving the goal become a new goal, thereby becoming the main factor declaring the level of development of the economic power of the state" [5]. Any society aiming to achieve sustainable progress, should the path of development to choose an innovation-based economy. And Russia is no exception here. Repeatedly at the highest level of government, the leaders of our country declared the priority role of the innovation system in the Russian economy.

\section{B. Strategy of innovative development in the long-term perspective of transformation of the Russian economy}

According to the Forecast of long-term social and economic development of the Russian Federation till 2030 [4], there are three scenarios of social and economic development in the long-term perspective - conservative, innovative and target (forced). The innovative scenario (most likely) is characterized by an increase in the investment orientation of economic growth, based on the creation of modern transport infrastructure and a competitive sector of high-tech industries and the knowledge economy, along with the modernization of the energy and raw materials complex. The scenario involves the transformation of innovative factors into a leading source of economic growth. The main forecast indicators of social and economic development of the Russian Federation for 2016 - 2030 in accordance with the innovative development scenario are summarized in the table. III.

Based on the traditional competitive advantages of the Russian economy in addition to the development of new knowledge-intensive areas and the "knowledge economy", the innovative development scenario provides for the implementation of such measures as:

- Improving the efficiency of the national innovation system, increasing the volume of segments of medium and high-tech goods in world markets.

- The development of competitive innovative clusters, the concentration of development in regional centres.
TABLE II. DISTINCTIVE FEATURES OF THE NEW ECONOMY

\begin{tabular}{|c|c|c|}
\hline № & $\begin{array}{c}\text { Distinctive } \\
\text { feature }\end{array}$ & Disclosure \\
\hline 1 & $\begin{array}{l}\text { The } \\
\text { dominant } \\
\text { role of the } \\
\text { human } \\
\text { factor } \\
\text { among the } \\
\text { driving } \\
\text { forces } \\
\text { behind the } \\
\text { developme } \\
\text { nt }\end{array}$ & $\begin{array}{l}\text { Human capital, creative original thinking, the ability to } \\
\text { constant learning and development, the level of } \\
\text { education and competence - it is in the new economy, } \\
\text { these factors have gained considerable weight, a greater } \\
\text { role in ensuring the activities of the organization, came } \\
\text { to the forefront in comparison with the use of traditional } \\
\text { resources. }\end{array}$ \\
\hline 2 & $\begin{array}{c}\text { Globalizati } \\
\text { on of } \\
\text { markets }\end{array}$ & $\begin{array}{l}\text { Previously, the location of an enterprise or business } \\
\text { played a significant role in the issue of accessibility for } \\
\text { the consumer, in many cases resulting in a competitive } \\
\text { advantage. In the context of globalization of markets } \\
\text { and the development of information technology, the } \\
\text { consumer is not only available to all producers, } \\
\text { including those thousands of miles away on other } \\
\text { continents, but often there is no need to leave home for } \\
\text { shopping. Everything becomes available to all via the } \\
\text { Internet. Accordingly, manufacturers acquire } \\
\text { competitors not only in their field or country, but also in } \\
\text { other countries. }\end{array}$ \\
\hline 3 & $\begin{array}{l}\text { Knowledge } \\
\text { as the main } \\
\text { source of } \\
\text { wealth, the } \\
\text { main } \\
\text { productive } \\
\text { force of the } \\
\text { economy }\end{array}$ & $\begin{array}{l}\text { In modern dynamic organizations have already clearly } \\
\text { known and accepted on arms that human knowledge is } \\
\text { a productive force, the ability to apply them becomes a } \\
\text { source of growth of wealth, the intellectual component } \\
\text { is no less important and often outweighs the traditional } \\
\text { material factors of production }\end{array}$ \\
\hline 4 & $\begin{array}{l}\text { The effect } \\
\text { of } \\
\text { instantaneo } \\
\text { us growth }\end{array}$ & $\begin{array}{l}\text { If in a traditional economy a product or service must go } \\
\text { through all stages of development in accordance with } \\
\text { the life cycle of the product, should be used all the tools } \\
\text { of promotion, in the new economy are not rare cases } \\
\text { where due to an instant reaction to the high-speed } \\
\text { transmission of information, wins and wins the market } \\
\text { is the firm that was able to first interpret the positive } \\
\text { information and quickly So information is disseminated } \\
\text { virtually instantly, the management of companies must } \\
\text { also respond immediately, which again raises the } \\
\text { human factor in the underlying drivers of development. }\end{array}$ \\
\hline 5 & $\begin{array}{l}\text { The high } \\
\text { dynamism } \\
\text { of } \\
\text { processes. } \\
\text { Immediate } \\
\text { reaction of } \\
\text { the market }\end{array}$ & $\begin{array}{l}\text { On the background of a ubiquitous information } \\
\text { technologies the market actors have the ability to } \\
\text { communicate in real time, to track changes in market } \\
\text { conditions, immediately react, to take immediate } \\
\text { management decisions. The high speed of market } \\
\text { processes in the new economy contributes to the } \\
\text { creation of new value, wealth, abundance and diversity } \\
\text { on the commodity market. }\end{array}$ \\
\hline 6 & $\begin{array}{c}\text { Market } \\
\text { virtualizatio } \\
n\end{array}$ & $\begin{array}{l}\text { In the traditional economy, the markets had certain } \\
\text { barriers associated with territorial remoteness, lack of } \\
\text { information, the need for personal travel over long } \\
\text { distances in search of business partners or buyers. In the } \\
\text { new economy, these barriers disappear. Information can } \\
\text { be found as soon as possible about the subject of the } \\
\text { market at any distance, instantly to contact entities, the } \\
\text { buyer has the opportunity to find information on the } \\
\text { entire range of interesting products and services and } \\
\text { close the deal. }\end{array}$ \\
\hline 7 & $\begin{array}{c}\text { The } \\
\text { combinatio } \\
\mathrm{n} \text { of market } \\
\text { stages }\end{array}$ & $\begin{array}{l}\text { As noted above, a developing product or service does } \\
\text { not need to go through all stages of its life cycle. The } \\
\text { conditions of the new economy allow to combine many } \\
\text { stages. For example, you can simultaneously search for } \\
\text { customers, promote goods, make a deal, sell, buy, etc. }\end{array}$ \\
\hline
\end{tabular}


- Deepening the specialization of the Russian Federation in the market of high-tech products in such industries as aviation and space industry, shipbuilding, nuclear technology, software, space launch services and communications, navigation and geographic information support.

To achieve the goals of innovative development stated in the Forecast of long-term socio-economic development of the Russian Federation until 2030, it is necessary to build effective mechanisms of interaction between business, society and the state, using coordination of efforts of all parties, taking into account the interests of different social groups of society and business. Becoming on the innovative path of economic development requires the creation of the most favorable conditions for the growth of entrepreneurs ' initiatives, increasing the investment attractiveness and competitiveness of Russian companies, as it is private business that is the main driver of economic development. The state should create the necessary conditions and incentives for business development, but should not replace the entrepreneurial initiative with its instruments.

\section{Monitoring of scientific, technical and innovation activities in the Astrakhan region}

The identified factors of innovation and technical priorities of the Russian economy in the long term require the coordination and development of scientific, technical and innovation activities in the regions. Monitoring coordination and development of scientific-technical and innovation

TABLE III. BASIC FORECAST INDICATORS OF SOCIO-ECONOMIC DEVELOPMENT OF RUSSIA FOR 2016-2030 IN ACCORDANCE WITH INNOVATIVE SCENARIO OF DEVELOPMENT

\begin{tabular}{|c|c|c|c|c|c|}
\hline Indicators & Unit & $\begin{array}{l}2016- \\
2020\end{array}$ & $\begin{array}{l}2021- \\
2025\end{array}$ & $\begin{array}{l}2026- \\
2030\end{array}$ & $\begin{array}{l}2013- \\
2030\end{array}$ \\
\hline $\begin{array}{l}\text { Gross domestic } \\
\text { product }\end{array}$ & $\begin{array}{l}\text { the average } \\
\text { annual } \\
\text { growth rate } \\
\text { in } \%\end{array}$ & 4.4 & 4,0 & 3,7 & $4,0-4,2$ \\
\hline Industry & $*$ & 3,4 & 3,0 & 2,9 & 3,2 \\
\hline $\begin{array}{l}\text { Investments in } \\
\text { fixed assets }\end{array}$ & $*$ & 6,6 & 5,5 & 4,8 & 5,9 \\
\hline Real wages & $*$ & 5,4 & 4,6 & 4,1 & 4,8 \\
\hline $\begin{array}{l}\text { Retail trade } \\
\text { turnover }\end{array}$ & $*$ & 4,7 & 4,4 & 4,2 & 4,6 \\
\hline $\begin{array}{l}\text { Export-total (at } \\
\text { the end of the } \\
\text { period), billion } \\
\text { dollars }\end{array}$ & $*$ & 705 & 989 & 1438 & -- \\
\hline $\begin{array}{l}\text { Imports-total (at } \\
\text { the end of the } \\
\text { period), billion } \\
\text { dollars }\end{array}$ & $*$ & 574 & 765 & 1067 & -- \\
\hline $\begin{array}{l}\text { Expenditure on } \\
\text { education }(5.2 \% \\
\text { in } 2010)\end{array}$ & $\begin{array}{l}\% \text { from } \\
\text { GDP }\end{array}$ & $\begin{array}{l}6 \% \text { in } \\
2020\end{array}$ & -- & $\begin{array}{c}6,5 \% \text { in } \\
2030\end{array}$ & -- \\
\hline $\begin{array}{c}\text { Spending on } \\
\text { science }(1.2 \% \text { in } \\
2010)\end{array}$ & $*$ & -- & -- & $\begin{array}{c}2,5 \% \text { in } \\
2030\end{array}$ & -- \\
\hline
\end{tabular}

activities in the Astrakhan region has allowed to identify the main trends and indicators of this process.

The basis of regional science consists of 4 state universities, 4 research institutes (Caspian research Institute of fisheries, all-Russian research Institute of irrigated vegetable and melon production, Caspian research Institute of arid agriculture, research Institute for the study of leprosy of the Ministry of health of Russia), Caspian marine research center, biosphere reserve, a branch of the Institute of Oceanology. The above-mentioned organizations have quite a serious scientific potential: more than 3,000 people engaged in research, including 340 doctors of science, 1350 candidates of science. Annually more than 200 specialists of higher qualification graduate schools are graduated [6].

In the Astrakhan region, special attention is paid to staffing the development of innovative economy. Astrakhan region has 18 higher educational institutions, 22 scientific organizations, including in the field of fisheries, aquaculture, oil and gas complex, arid agriculture, etc.

In order to improve the innovative potential of the Astrakhan region, a multilevel system of innovation support has been formed in the Region, which can help in the individual development of talented young people, as well as in the formation of innovative companies at each stage of development. The multi-level system of innovation support in the Astrakhan region consists of the following steps:

Step 1. Children and youth educational cluster in the field of scientific and technical creativity. Includes: two youth innovation creativity centre (YICC); Techno park regional school; internship site for school teachers; the center for children's scientific and technical creativity for children of primary school age; the branches of the Techno park and a mug of robotics and direct digital manufacturing in schools. More than 7000 children went through Techno park and YICC with their projects. More than five thousand children living in rural areas have implemented their projects on the basis of their clubs and with the remote support of specialists of Techno park and YICC.

Step 2. Implementation of the grant program of the Fund for assistance to innovations "UMNIK" in the territory of the Astrakhan region. Under this program, young innovators aged 18 to 30 years can receive funds for the development of their project in the amount of 500 thousand rubles for a period of 2 years. In September 2016, 158 applications were submitted for the competition under this program. Summary -8 the winners of the program UMNIK.

Step 3. The government of Astrakhan region signed an agreement on cooperation with the SKOLKOVO Foundation, Fund for the promotion of innovation, RUSNANO. Within the framework of the concluded agreements, active interaction with the listed structures is carried out. In March 2016, the regional stage of the contest "Innovative quarter" was held on the Basis of the Astrakhan Techno park FABRIKA. In 2016, Europe's largest conference for young innovators, investors and venture capital professionals Startup Village in 2016 was attended by residents of Techno park in Astrakhan FABRIKA. 
Step 4. The main infrastructure of the state support is concentrated in the Autonomous institution of the Astrakhan region "Astrakhan regional innovation center". At the Center are the center for cluster development, regional integrated centre, regional center of engineering, centre of social innovations, business incubators. Services are provided to innovative companies in the preparation of business plans, registration of applications for competitions and grants, determination of the index of technological readiness, search for partners in foreign countries, marketing research, branding, organization of visits to exhibitions, conferences, training in various areas.

Step 5. In September 2016, the project "Innovations without obstacles" was launched, the main goal of which is to support students, young scientists, startups, innovative companies at any stage of the development and implementation of the innovation project. A team of representatives of the Ministry of economic development of the Astrakhan region, SME support and innovation centers, private technology Park, and successful innovation companies was formed. The project team visited 5 Universities, a forum, a competition of innovative it projects "IT Caspian". More than 650 people received advice on support for innovative activities.

Systematic and long-term work to support innovation in the Astrakhan region has contributed to the fact that the sector of innovative entrepreneurship plays an increasingly prominent role in the economy of the region. New requirements for the development of regional industry have increased the receptivity of business to innovation.

The dynamics of indicators in the field of research and innovation in the Astrakhan region is presented in table IV.

We see that most parameters in the field of scientific research and innovation in the Astrakhan region in 2012-2016 there is a positive trend. However, there was a decrease in the number of employees who carried out research and development by 2016 by $31.76 \%$ compared to 2012 , the internal cost of research and development by $19.7 \%$. The total number of innovative companies in the Astrakhan region is 236. The positive dynamics of the Astrakhan region in the ratings of innovation activity of the regions.

\section{CONCLUSION}

The policy of the government of the Russian Federation regarding long-term social and economic development assumes strengthening of competitive advantages on the basis of breakthrough in transition to economy of new type, innovative socially-oriented, competitive in the world space.

The marked distinctive features of the" new economy " and the direction of innovative development of the Russian economy in the long term determine their use as strategic priorities, in the first turn, at the level of regions, which will inevitably contribute to the strengthening of competitive positions, both the regions and the country as a whole.
TABLE IV. INDICATORS OF SCIENTIFIC RESEARCH AND INNOVATION IN THE ASTRAKHAN REGION IN THE PERIOD 2012-2016 [7]

\begin{tabular}{|c|c|c|c|c|c|c|c|}
\hline Indicators & Unit & 2012 & 2013 & 2014 & 2015 & 2016 & $\begin{array}{c}\text { Growth } \\
\text { rate } \\
2016 \text { / } \\
2012, \%\end{array}$ \\
\hline $\begin{array}{c}\text { Number of } \\
\text { organizations } \\
\text { doing research and } \\
\text { development }\end{array}$ & units & 17 & 20 & 20 & 25 & 24 & $\begin{array}{c}141,18 \\
\%\end{array}$ \\
\hline $\begin{array}{l}\text { The number of } \\
\text { employees } \\
\text { performing } \\
\text { research and } \\
\text { development }\end{array}$ & $\operatorname{man}$ & 1014 & 1083 & 904 & 933 & 692 & $68,24 \%$ \\
\hline $\begin{array}{l}\text { Domestic } \\
\text { expenditures on } \\
\text { research and } \\
\text { development }\end{array}$ & $\begin{array}{l}\text { milli } \\
\text { on. }\end{array}$ & 572,9 & 568,8 & 549,9 & 563,1 & 458,5 & $80,03 \%$ \\
\hline $\begin{array}{l}\text { Financing of } \\
\text { science from the } \\
\text { Federal budget }\end{array}$ & $*$ & 156,6 & 188,7 & 147,3 & 420,1 & 280,4 & $\begin{array}{c}179,05 \\
\%\end{array}$ \\
\hline $\begin{array}{l}\text { The share of } \\
\text { organizations that } \\
\text { carried out } \\
\text { technological } \\
\text { innovations in the } \\
\text { total number of } \\
\text { organizations }\end{array}$ & $\%$ & 5,8 & 9,7 & 11,6 & 10,8 & 8,5 & -- \\
\hline $\begin{array}{l}\text { Expenditure on } \\
\text { technological } \\
\text { innovation }\end{array}$ & $\begin{array}{l}\text { milli } \\
\text { on. }\end{array}$ & 868,1 & 1069,6 & $\begin{array}{c}3537 \\
8\end{array}$ & $\begin{array}{c}1911, \\
1\end{array}$ & $\begin{array}{c}3679 \\
3\end{array}$ & $\begin{array}{c}\text { increase } \\
\mathrm{d} \text { by } \\
4,24 \\
\text { times }\end{array}$ \\
\hline $\begin{array}{l}\text { Volume of shipped } \\
\text { innovative goods, } \\
\text { works and services }\end{array}$ & $*$ & 450,6 & 2604,9 & $\begin{array}{c}8477 \\
7\end{array}$ & $\begin{array}{c}1045 \\
6,5\end{array}$ & $\begin{array}{c}13036 \\
, 4\end{array}$ & $\begin{array}{l}\text { increase } \\
\mathrm{d} \text { by } \\
28,93 \\
\text { times }\end{array}$ \\
\hline $\begin{array}{c}\text { Share of } \\
\text { organizations that } \\
\text { implemented } \\
\text { organizational } \\
\text { innovations in the } \\
\text { total number of } \\
\text { organizations }\end{array}$ & $\%$ & 1,6 & 1,6 & 2,1 & 1,7 & 1,7 & -- \\
\hline
\end{tabular}

\section{References}

[1] Avdokushin E. F. the New economy // Modern high technologies. - 2010. - № 10 - Pp. 223-225/

[2] Transition to a new economy: economic, technological, Commerce and social aspects [Electronic resource] / Business Engineering Group.- URL: http://bigc.ru/publications/other/concepts/pereh_k_new_ekonom.php

[3] Local Residents. A. Innovative economy and new economy: the ratio of processes and panty / A. A. Locals // West Cargo state socio-economic University.- 2013.- No. 1.- S. 128-131.

[4] Draft Concept of long-term socio-economic development of the Russian Federation [Electronic resource] / "Consultant Plus"information and reference system.- URL: http://base.consultant.ru/cons/cgi/online.cgi?req=doc;base=law;N=90601

[5] On Nightingales. A. Features of the" new national economy " of Russia // vest Chelyabinsk state University. Management. - 2014.- No. 2 (331).Pp. 23-24.

[6] the Socio-economic development in the region Strands 2016: official $\begin{array}{llll}\text { report [Electronic resource].- } & \text { URL: }\end{array}$ https://www.astrobl.ru/sites/default/files/uploads/doklad_o_socialno_eko nomicheskom_razvitii_2016.pdf

[7] Statistics Yearbook Strands area [Electronic resource].- URL: http://astrastat.gks.ru/wps/wcm/connect/rosstat_ts/astrastat/ru/publication s/official_publications/electronic_versions/ 